\title{
Genetic Control of Testis Development
}

\author{
R. Sekido R. Lovell-Badge \\ Division of Stem Cell Biology and Developmental Genetics, MRC National Institute for Medical Research, \\ London, UK
}

\section{Key Words}

Sertoli cell · Sex determination - Sox $9 \cdot \operatorname{SRY} \cdot$ TESCO $\cdot$ Testis

formation $\cdot$ Transdifferentiation

\begin{abstract}
Sex determination refers to the decision of the bipotential early gonads to develop as either testes or ovaries during embryogenesis. In mammals, a single genetic trigger involved in this pivotal decision has been identified on the $Y$ chromosome: the testis-determining gene SRY/Sry. During embryogenesis, SRY triggers the differentiation of Sertoli cells from the supporting cell precursor lineage which would otherwise give granulosa cells in ovaries. Several testis-specific events occur after SRY expression and the onset of Sertoli cell differentiation, notably Leydig cell differentiation, testis cord formation, and development of testis-specific vasculature. Although a number of genes involved in these events have been identified, how they relate to Sry action is poorly understood. Furthermore, even at the adult stage, some of these genes retain a key role in maintaining the testicular fate because conditional ablation of the genes leads to adult testis dysgenesis or transdifferentiation into an ovary. This sheds light on mammalian sex-reprogramming, despite the prevailing dogma that postnatal sex change does
\end{abstract}

not occur in mammals. In this review, we summarize our current understanding of genetic pathways of testis determination and differentiation in mammals, particularly in the mouse and the human.

Copyright $\odot 2012$ S. Karger AG, Basel

\section{SRY: Mammalian Testis-Determining Gene}

Human SRY was identified by looking for conserved sequences within $35 \mathrm{~kb}$ of $\mathrm{Y}$ chromosome-unique sequences translocated to the $\mathrm{X}$ chromosome in $\mathrm{XX}$ individuals showing some male characteristics. Point mutations were also discovered within the $S R Y$ coding region in several XY females, indicating that $S R Y$ is required for male development [Sinclair et al., 1990]. The mouse homologue, Sry, was found to be present in the smallest region of the Y chromosome associated with male development but was missing from a mutant $Y$ chromosome due to an 11-kb deletion that led to XY female development [Gubbay et al., 1990]. Subsequent experiments demonstrated that a transgene comprising $14 \mathrm{~kb}$ of Sry genomic sequences causes XX sex reversal when introduced into mice [Koopman et al., 1991]. SRY/Sry is a member of the SOX gene family that encodes HMG-box transcription

\section{KARGER \\ Fax +4161306 1234 \\ E-Mail karger@karger.ch}

www.karger.com
(C) 2012 S. Karger AG, Basel

$1661-5425 / 13 / 0073-0021 \$ 38.00 / 0$

Accessible online at:

www.karger.com/sxd
Ryohei Sekido or Robin Lovell-Badge

Division of Stem Cell Biology and Developmental Genetics

MRC National Institute for Medical Research

The Ridgeway, Mill Hill, London NW7 AA (UK)

Tel. +44 208816 2126, E-Mail rsekido@nimr.mrc.ac.uk or rlovell@nimr.mrc.ac.uk 
factors. To date, Sry homologues have been identified in other eutherian and metatherian mammals, but not in monotremes. Although amino acid sequences of SRY proteins vary with species, except for the HMG box, the testis-determining activity of SRY is conserved because $\mathrm{XX}$ sex reversal occurs in transgenic mice carrying $S R Y$ derived from different species, such as the human and the goat [Lovell-Badge et al., 2002; Pannetier et al., 2006].

The SRY gene exists in almost all placental mammals (eutherians) and marsupials (metatherians) but not in the monotremes, such as the platypus and the echidna [Grützner et al., 2004; Wallis et al., 2008]. It is most often a single copy gene in eutherians, with a few exceptions; notably the rat carries at least 6 copies [Turner et al., 2007]. Apart from the HMG box, the structure of the $S R Y$ gene is poorly conserved at both nucleotide and amino acid levels; indeed it shows very rapid evolution. The mouse Sry gene has a distinct structure from other mammalian SRY genes because of the presence of a long inverted repeat flanking a relatively small unique region that contains the open reading frame. This allows a stem loop structure to form in primary transcripts that initiate in the $5^{\prime}$-repeat and extend through to the $3^{\prime}$-repeat. The proximity of 3 '-splice acceptor and 5'-donor sites in the loop facilitates pre-mRNA splicing to produce a circular transcript that is not translated [Capel et al., 1993]. This is in contrast to the functional linear Sry transcript present in Sertoli cell precursors which initiates within the unique region to give Sry mRNA that can be translated into SRY protein [Hacker et al., 1995]. The circular transcript is detectable in differentiated Sertoli cells at 13.5 days post coitum (dpc) [Dolci et al., 1997] and is predominantly expressed in adult germ cells, particularly in round spermatids [Capel et al., 1993]. In other eutherians, SRY expression is not restricted to the embryonic Sertoli cell lineage. For example, goat SRY is expressed in all types of somatic cells and germ cells in the gonad throughout the embryonic stage and restricted to Sertoli cells and spermatogonia in the adult testis, although at a low level in the latter [Montazer-Torbati et al., 2010]. Human SRY is also expressed in both Sertoli cells and germ cells at fetal and adult stages [Salas-Cortes et al., 1999]. SRY is also known to be expressed in specific regions of the brain, at least in mice and rats [Dewing et al., 2006], where it could confer sex-specific differences independently of those induced by the high levels of androgen made by the testis [McCarthy and Arnold, 2011].

The study of Sry variants in the mouse has been very informative. Thus, the transfer of a specific Mus domesticus $\mathrm{Y}$ chromosome ( $\mathrm{Y}^{\mathrm{DOM}}$ ) onto C57BL/6J (B6) inbred strain background affects testis development [Eicher et al., 1982; Nagamine et al., 1987]. For example, B6 mice carrying a $\mathrm{Y}$ chromosome of $M$. domesticus poschiavinus $\left(\mathrm{Y}^{\mathrm{POS}}\right)$ show complete or partial sex reversal, and a $\mathrm{Y}$ chromosome of AKR/J ( $\mathrm{Y}^{\mathrm{AKR}}$ ) causes a delay in testis cord formation on a B6 background, whereas other strains including DBA/2J (D2) and 129S1/SvJ (129S) are resistant to these $\mathrm{Y}^{\mathrm{DOM}}$ effects. SRY expression is also delayed from $\mathrm{Y}^{\mathrm{POS}}$ and $\mathrm{Y}^{\mathrm{AKR}}$ in the former cases, compared to that from $\mathrm{Y}^{\mathrm{B} 6}$ [Bullejos and Koopman, 2005]. The evidence implies an abnormal interaction between $S r y^{\mathrm{DOM}}$ and allele(s) carried on B6 autosomes or X chromosome. A genetic linkage analysis between $\mathrm{B} 6$ and $\mathrm{D} 2$ demonstrated that autosomal loci sensitive to $\mathrm{Y}^{\mathrm{POS}}$-associated sex reversal, designated as tda1, 2, and 3, mapped on chromosome 2, 4, and 5, respectively [Eicher et al., 1996]. In addition, by generating B6/129S congenic strains carrying $\mathrm{XY}^{\mathrm{POS}}$, a locus protecting against $\mathrm{XY}^{\mathrm{POS}}$ sex reversal was identified on chromosome 11 of $129 \mathrm{~S}$ [Nikolova et al., 2008]. Recent studies of expression of quantitative trait loci elucidated thousands of genes differentially expressed between B6 and 129S [Munger et al., 2009]. Although these analyses demonstrated both known and novel candidates for genes responsible for sex determination/differentiation, they have so far still been insufficient to fully explain B6-associated sex reversal. However, they did show that around the time of sex determination B6 XY gonads show relatively higher expression levels of ovary- versus testis-promoting genes, suggesting that they are more prone to follow the ovarian pathway. The exception was $\operatorname{Sox} 9$ which was elevated. This is a key target of SRY required for testis determination (see below), suggesting that B6-associated sex reversal occurs when Sox9 transcription or activity is compromised.

\section{Genes Upstream of SRY}

How is Sry transcription activated in the male gonad? In early gonad development, proliferative coelomic epithelial cells migrate into the gonad, and a subset of the post-migratory cells becomes supporting cell precursors. These are SRY-positive in an XY embryo from about 10.75-12.5 dpc (12-27 tail somite stages) [Bullejos and Koopman, 2001; Sekido et al., 2004]. Several transcription factors have been implicated in Sry expression in this cell lineage. Steroidogenic factor 1 (SF1), also known as NR5A1, is an orphan nuclear receptor transcription factor whose expression begins in the coelomic epithelium at $9.5 \mathrm{dpc}$ and continues in both supporting and steroido- 
genic cells. Haploinsufficiency of $S F 1$ can cause XY sex reversal in humans [Mallet et al., 2004; Lin et al., 2007], although it usually leads to normal testis development in mice (except on a B6 background). In XY Sf1 ${ }^{-/-}$homozygous null mutant mice, the gonads start to degenerate after $11.5 \mathrm{dpc}$ and are completely absent by $12.5 \mathrm{dpc}$ [Luo et al., 1994]. Since no Sry expression is observed in these gonads, SF1 is a good candidate for a Sry activator [Guioli and Lovell-Badge, unpubl. data]. LIM homeobox 9 (LHX9) expression also begins in the coelomic epithelium at $9.5 \mathrm{dpc}$, although it eventually localizes to cells in the interstitium rather than to supporting cells when testis development proceeds [Birk et al., 2000]. Mice lacking the $L h x 9$ gene exhibit a significant reduction of $S f 1$ expression and display gonadal agenesis as seen in $S \mathrm{fl}^{-/-}$ mice. Therefore, Sry might be indirectly regulated by LHX9 through Sf1. The expression pattern of Wilms' tumor suppressor gene 1 (WT1), encoding a zinc finger transcription factor, is similar to that of $S f 1$. WT1 produces 24 isoforms caused by combinations of alternative splicing, different start codon usage, and RNA editing. The exon 9 splicing variants, giving the presence or absence of KTS amino acids between zinc fingers 3 and 4, namely WT1(+KTS) or WT1(-KTS), are well studied in sex determination. In humans, loss-of-function (LOF) mutations of the WT1(+KTS) form cause Frasier syndrome which is characterized by an XY sex reversal associated with urogenital abnormalities. A homozygous targeted deletion of WT1(+KTS) in mice also results in a reduction of Sry expression and thus an XY sex reversal phenotype [Hammes et al., 2001]. On the other hand, in cooperation with LHX9, WT1(-KTS) binds to the Sf1 promoter and activates its expression [Wilhelm and Englert, 2002].

GATA-binding protein 4 (GATA4) and its cofactor Friend of GATA2 (FOG2) are also involved in testis determination and differentiation because testis development is abnormal in XY gonads carrying a Fog $2^{-/-}$homozygous null mutation or a Gata $4^{k i}$ homozygous allele where a crucial amino acid required for interacting with FOG2 is mutated. In particular, Sry expression is significantly reduced in the Fog2 ${ }^{-/-}$gonad [Tevosian et al., 2002]. Chromobox homolog 2 (Cbx2), also known as M33, is an orthologue of the Drosophila Polycomb gene and is thought to regulate transcription by changing chromatin status. LOF mutations of $C b x 2$ cause XY sex reversal in both mice and humans [Katoh-Fukui et al., 1998; BiasonLauber et al., 2009]. Growth defects are observed in the genital ridge as soon as Sry expression begins, although a genetic interaction between $C b x 2$ and Sry is unclear.

Genetic Control of Testis Development
CBX2 might regulate Sry expression through $S f 1$, because CBX2 directly binds to the genomic locus of $S f 1$, as shown by chromatin immunoprecipitation (ChIP) assays, and $S f 1$ expression is significantly reduced in $C b \times 2$ mutant mice. However, CBX2 might affect other critical parameters such as cell proliferation which is required to have sufficient numbers of supporting cell precursors to differentiate into Sertoli cells. When cell proliferation is compromised directly, this can also lead to XY ovary formation [Schmahl and Capel, 2003].

In addition to the transcription factors shown above, signaling molecules involved in receptor tyrosine kinase activity are also important for initial stages of sex determination. For example, combined LOF mutations of the insulin receptor (Ir), the insulin-related receptor (Irr), and the insulin-like growth factor 1 receptor (Igflr1) genes cause an overall reduction in Sry expression [Nef et al., 2003]. However, because cell proliferation can be dependent on insulin signaling, this may reflect reduced cell numbers rather than reduced Sry transcription. Furthermore, mitogen-activated protein kinase kinase kinase 4 (Map3k4) was identified as the gene responsible for the boygirl (byg) mutant phenotype in a forward genetic screen in mice using ENU mutagenesis [Bogani et al., 2009]. Byg is a nonsense mutation in the coding region of Map3k4, causing a truncation of the receptor tyrosine kinase domain. In XY byg homozygous mutant mice, Sry expression is dramatically reduced and testis-specific cellular events (i.e. those occurring downstream of Sry), such as proliferation of coelomic epithelial cells and mesonephric cell migration, are impaired. Ovary-promoting genes are upregulated instead, resulting in XY female sex reversal. Similar to byg, MAP3K1 mutations in humans cause 46,XY disorders of sexual development with partial or complete gonadal dysgenesis [Pearlman et al., 2010]. Map3k4 maps within the $t$-complex locus on mouse chromosome 17. In the presence of $\mathrm{Y}^{\mathrm{AKR}}$, deletions at the $t$-complex cause a male-to-female sex reversal, so called $t$-associated sex reversal (Tas), when placed on a B6 background [Washburn and Eicher, 1983]. T-hairpin tail ( $\left.T^{h p}\right)$ and T-Orleans $\left(T^{\text {orl }}\right)$ are well-known alleles of Tas, and Map3k4 is lost in both cases. Indeed, XY byg/+; Thp/+ compound heterozygous mice show a similar phenotype to $\mathrm{XY} b y g / b y g$. Moreover, similar to Tas, haploinsufficiency of Map3k4 leads to sex reversal on B6, i.e. B6-XYAKR byg/+. The evidence suggests that Map3k4 is the gene responsible for Tas, although the presence of other genes in the Tas locus cannot be ruled out.

Sry expression is very transient in the mouse $\mathrm{XY}$ gonad, probably occurring for as little as $4 \mathrm{~h}$ in each sup- 
porting cell precursor, unless Sox9, its direct target (see below), fails to be activated in which case it persists [Lee and Taketo, 1994; Chaboissier et al., 2004; Sekido et al., 2004]. This suggests that SOX9 directly or indirectly leads to repression of Sry, although there is as yet no evidence for this.

\section{Genes Downstream of SRY}

An essential process in testis determination is the upregulation of SOX9 expression by SRY. It is known that LOF mutations in human SOX9 cause campomelic dysplasia which is often associated with XY sex reversal [Foster et al., 1994; Wagner et al., 1994], while gain-of-function (GOF) mutations, such as gene duplication, can lead to XX sex reversal [Huang et al., 1999]. Similarly, in mice, both LOF and GOF mutations in the gene mimic those of Sry. For example, Odd sex (Odsex) mutant mice, where Sox9 is constitutively activated in the gonad, exhibit an XX male phenotype [Bishop et al., 2000]. Misexpression of Sox9 under the control of the WT1 promoter also causes XX sex reversal [Vidal et al., 2001]. Mice carrying the endogenous Sox 9 allele flanked by loxP sites, so called 'floxed' Sox9 or Sox $9^{\text {flox/flox }}$, show XY sex reversal when the allele is removed by tissue-specific Cre transgenes, such as Sf1-Cre and cytokeratin-Cre (Ck19-Cre) for the coelomic epithelium, or by the use of protamine-Cre (Prm1-Cre) and zona pellucida-Cre (ZP3-Cre) in the germline [Chaboissier et al., 2004; Barrionuevo et al., 2006]. Based on genetic evidence and expression studies, it was proposed that gonadal Sox 9 expression is initiated (at a low level) by SF1 in both sexes at $10.5 \mathrm{dpc}$ and then strongly up-regulated immediately after the onset of Sry expression, whereas it is actively down-regulated in the ovary [Morais da Silva et al., 1996; Sekido et al., 2004]. A $3.2 \mathrm{~kb}$ testis-specific enhancer of Sox9 (TES) or $1.4 \mathrm{~kb}$ of its core element (TESCO) mediating this expression pattern was then identified approximately $14 \mathrm{~kb}$ upstream of the Sox9 promoter [Sekido and Lovell-Badge, 2008]. Indeed, SRY and SF1 directly bind to several sites within TES, shown by ChIP assays, and synergistically activate the activity of this enhancer. Moreover, together with SF1, SOX9 also binds and activates TES, indicating that SOX9 maintains its own expression by autoregulation after transient SRY expression has ceased.

The TES sequence is also found upstream of Sox 9 in other vertebrates. However, the degree of conservation decreases rapidly with evolutionary distance. For example, TES seems to be well-conserved overall amongst eu- therians, but only a part of TES is present in opossum, platypus, chicken, lizard, and frog, whereas no similar sequences are apparent in fish [Sekido and Lovell-Badge, 2008; Bagheri-Fam et al., 2010]. Deletions or rearrangements might have occurred during evolution. The question therefore remains whether TES is functionally conserved. Human TES sequence has been tested for a testisspecific enhancer activity in transgenic mice, but no activity was observed [Sekido, unpubl. data]. Although a number of human XY gonadal dysgenesis cases, where $S R Y$ is intact, have been investigated for mutation in the TES sequence, no mutation has been discovered [Georg et al., 2010]. Instead, a 46,XY patient carrying a $1.2-\mathrm{Mb}$ deletion approximately $300 \mathrm{~kb}$ upstream of human SOX9 shows no sign of campomelic dysplasia but only gonadal dysgenesis [White et al., 2011]. Furthermore, familial 46,XX SRY-negative testicular disorders have been reported with a $178-\mathrm{kb}$ duplication and a $96-\mathrm{kb}$ triplication in 500-600 kb upstream of human SOX9 [Cox et al., 2011; Vetro et al., 2011]. This data raises the possibility that regulatory elements distinct from TES exist upstream of human SOX9. It will be interesting to see if these are responsible for tissue-specific expression or if they help to ensure appropriate levels of $S O X 9$ transcription.

Expression of SOX9 in the early gonad in the absence of SRY can lead to XX male sex reversal, making it likely that Sox9 is the only critical direct target of SRY. Nevertheless, even if SOX9 is sufficient, it is possible that SRY might also participate in the regulation of other genes. Such a role may be minor, especially as SRY has at best weak transactivation properties and is present very transiently. Indeed it is likely that SOX9 action will swamp that of SRY, given its very robust expression, strong transactivation properties, and ability to bind the same binding sites as SRY [Sekido and Lovell-Badge, 2008]. Other candidates for direct targets of SRY have been proposed from gene expression studies, but molecular and genetic data to identify and ultimately test specific interactions between SRY and relevant enhancers is required for verification [Canning and Lovell-Badge, 2002]. Alternatively, ChIP technology has been used to search for targets, but the mere presence of SRY bound to DNA (or bound via an interacting factor) does not prove it is doing anything without appropriate gene expression data and mutation studies to suggest that the interaction is relevant. For example, Pod1, also known as Tcf21/bHLHa23/ capsulin/epicardin, which encodes a basic helix-loop-helix transcription factor, has been proposed as a direct target of SRY. In the rat, Pod1 expression is detected in somatic cells adjacent to germ cells at $13.0 \mathrm{dpc}$ and subse- 
quently in Sertoli cells at $14.0 \mathrm{dpc}$, and a few days later in the interstitium including fetal Leydig cells [Bhandari et al., 2011], although previous studies in the mouse demonstrated that Podl expression is restricted to the coelomic epithelium and interstitium including peritubular myoid cells in the embryonic testis [Tamura et al., 2001]. The rat Pod 1 promoter contains 3 SRY-binding sites which are conserved in the mouse and the human, and ChIP assays revealed that they are potential targets of SRY [Bhandari et al., 2011]. XY mice homozygous for a Pod1 null mutation (Pod1 ${ }^{-/-}$) exhibit defects in formation of testis cords and the testis-specific coelomic blood vessel. This partial sex reversal may be due to a decrease of endothelial cell migration from the mesonephros [Cui et al., 2004]. This suggests that Pod 1 could be a direct target; however, the gene also plays a role in early gonadal development irrespective of the presence of Sry, because its expression begins in both male and female genital ridges as early as $9.5 \mathrm{dpc}$. Indeed, both XY and XX Pod1 $1^{-/}$gonads are irregular in shape and smaller than wild-type gonads because of an increase of apoptosis. Consistent with a previous finding that POD1 represses Sf1 expression [Tamura et al., 2001], SF1 is ectopically expressed throughout $\mathrm{Pod}^{-/-}$gonads at $11.5 \mathrm{dpc}$, which might commit undifferentiated somatic progenitor cells to a steroidogenic lineage [Cui et al., 2004]. The later, apparently male-specific phenotype seen in XY gonads could therefore be an indirect effect of this earlier role and have nothing to do with SRY binding. Mutating the SRY binding site(s) in Pod1 may not be informative if SOX9 is required to maintain its expression, as both will bind the same sequence. In this case it becomes necessary to test what happens to Podl expression in the absence of both SRY and SOX9 and/or during XX male development when Sox9 is upregulated independently of SRY [see e.g. Sutton et al., 2011].

In rat testis development, neurotrophin 3 (NT3 or NTF3) is secreted from Sertoli cells and acts on its receptor trkC expressed in mesonephric cells. Inhibition of the trkC activity impairs mesonephric cell migration into the gonad and testis cord formation [Cupp et al., 2003]. Both rat and mouse Ntf3 promoters harbor a conserved SRYbinding site, determined by SRY-ChIP assays [Clement et al., 2011]. The Cerebellin 4 precursor gene $(C b \ln 4)$, which encodes a transmembrane protein, has also been suggested as a target of SRY [Bradford et al., 2009]. Cbln4 is initially expressed in both XY and XX gonads and is upregulated in the Sertoli cell lineage after SRY expression in the XY gonad, while it is down-regulated in the XX gonad. However, no biological function of $\mathrm{Cbl} 4$ has been described in testis development. Further work is therefore required in both cases to prove a direct and important role for SRY binding.

SOX proteins tend to have little effect on target gene transcription by themselves and function instead together with other transcription factors. As described above, SRY appears to act synergistically with SF1 to regulate Sox9 expression. It therefore follows that mutations within $S f 1$ or in other genes that alter its activity can also lead to XY female sex reversal. XY patients with a duplication of a 160-kb region of Xp21 display male-to-female sex reversal [Bardoni et al., 1994]. This region includes DAX1 (dosage-sensitive sex reversal (DSS), adrenal hypoplasia congenital (AHC) critical region on the $\mathrm{X}$ chromosome, gene 1), also known as NrOb1, encoding an unusual member of the nuclear receptor superfamily. Transgenic mouse experiments where the mouse homologue, Daxl, is overexpressed led to XY female development on specific backgrounds, showing that it is the gene responsible for DSS [Swain et al., 1998]. Furthermore, because Dax1 is initially expressed in the indifferent gonad of both sexes and then down-regulated in the testis and up-regulated in the ovary, it seemed possible that Daxl could be important for ovary differentiation. However, no signs of testis development are seen in XX mice homozygous for Dax1 mutations [Yu et al., 1998]; moreover, the transgenic mouse experiments were more consistent with it acting as an anti-testis gene, such that when overexpressed DAX1 could antagonize the ability of SRY to activate its target(s) [Swain et al., 1998]. Recent data suggests, however, that DAX1 does not directly interfere with SRY but with its partner, SF1. By recruiting co-repressors, excess DAX1 affects the ability of SF1 to work synergistically with SRY to activate Sox9 transcription, leading to XY female development [Ludbrook et al., 2012]. However, the story is perhaps even more complex, as Daxl expression itself is dependent on SF1 activity in the early genital ridge. It is lost in $S \mathrm{fl}^{-/-}$mice, and a critical enhancer upstream of Daxl contains SF1-binding sites which, when mutated, abrogate the expression of Dax1 [Hoyle et al., 2002]. Moreover, $\mathrm{X}^{\text {Daxl }}$ Y $\mathrm{Y}$ mice can show male-to-female sex reversal either in the presence of $\mathrm{Y}^{\mathrm{POS}}$ or on a congenic B6 background [Meeks et al., 2003; Bouma et al., 2005]. Since SF1 participates in many aspects of early gonad and then testis differentiation, including Sox9 upregulation, DAX1 may be required to modulate SF1 activity at earlier stages and perhaps help control the timing of events, such that its deletion can appear to have the same effect as its overexpression. 


\section{Spatiotemporal Regulation of Testis Determination}

Gene expression studies also show that early XX and $\mathrm{XY}$ gonads are poised to go along either the testis or the ovary pathway, with equal levels of factors that are known to become specific to, or more critical for, one or the other sex later on. This includes transcription factors such as SF1, WT1, SOX9, DAX1, etc., as well as signaling molecules like WNT4, R-spodin1 (Rspo1), and FGF9. It follows that expression of Sry in the XX gonad leads to upregulation of Sox9 expression and to testis development in a manner identical to that seen in XY gonads. However, the ability of the ectopic SRY to induce XX testes is confined to a narrow time window, reflecting the normal transient nature of Sry expression in the XY gonad. Studies using a heat-inducible Sry transgenic mouse line (Hsp70-Sry) demonstrated that testis development can be triggered in the XX gonad only for $6 \mathrm{~h}$ between 11.0 and $11.25 \mathrm{dpc}$ [Hiramatsu et al., 2009]. This result suggests that the expression of anti-testis or ovary-promoting genes increases over this period, reaching a critical threshold at about $11.25 \mathrm{dpc}$, beyond which Sox 9 expression can no longer either be upregulated by SRY (or a surrogate such as SOX3) [Sutton et al., 2011] or driven by subsequent positive autoregulatory loops. The latter involve, successively, SOX9 itself, FGF9, prostaglandin $\mathrm{D}_{2}$ $\left(\mathrm{PGD}_{2}\right), \mathrm{SOX} 8$, and SOX10 (see chapter 'Downstream Genes of Sox9'). Support for this comes from additional experiments using the Hsp70-Sry transgenic mice where it was found that loss of one allele of Wnt4, which acts as an anti-testis gene [Vainio et al., 1999; Jeays-Ward et al., 2003; Kim et al., 2006], allows heat-inducible expression of SRY at $11.5 \mathrm{dpc}$ to induce Sertoli cell differentiation and testis development [Hiramatsu et al., 2009]. Similarly, Daxl-dependent male-to-female sex reversal is more efficient in mice when Sry expression is delayed [Swain et al., 1998].

In contrast to transient expression of Sry, Sox 9 expression persists throughout life in Sertoli cells, suggesting that SOX9 executes and maintains their differentiation and aspects of their function. Against this notion, and while it is clear that SOX9 is essential earlier, it has been demonstrated that testis development is normal in

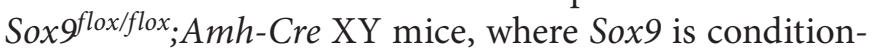
ally deleted at $14.0 \mathrm{dpc}$, although seminiferous tubules dysgenesis occurs approximately 5-6 months after birth [Barrionuevo et al., 2009]. However, this appears to be a relatively simple issue of functional redundancy. The other SoxE genes, i.e. Sox8 and Sox10, which both encode proteins very similar to SOX 9 , are up-regulated in the male gonad shortly after Sox 9 expression, suggesting that they may compensate loss of Sox9. Indeed, if Sox8 is also deleted along with Sox9, then Sertoli cell differentiation is not maintained and the gonads take on an ovarian phenotype [Barrionuevo et al., 2009].

Sry expression expands from the central domain to the poles along the anteroposterior axis of the XY gonad [Bullejos and Koopman, 2001; Sekido et al., 2004], and testis cord formation subsequently proceeds in a similar gradient manner. Consistent with this, both Sry and Sox 9 expression start in the central domain and reaches to the pole ends within several hours in XY gonad explants from 11.0 dpc embryos [Hiramatsu et al., 2010]. This expression pattern and timing occurs even when the explants are dissociated into 3 portions, i.e. anterior, central, and posterior, showing that it depends on intrinsic patterning. However, testis cord formation is impaired in both anterior and posterior explants. This suggests that there is also a requirement for non-cell autonomous factors secreted earlier or at higher levels from the center, and it has been recently shown that FGF9 is one of the factors.

\section{Genes Downstream of SOX9}

SOX9 autoregulates the TES sequence to maintain its own expression, as described above. Similarly, soon after Sox 9 expression, 2 other regulatory loops are established via FGF9 and $\mathrm{PGD}_{2}$. In the former, SOX9 directly or indirectly up-regulates Fgf9 expression and FGF9, in turn, maintains Sox9 expression through FGF receptor 2 (FGFR2) by establishing a feed-forward loop [Kim et al., 2006, 2007]. LOF mutations in either Fgf9 or Fgfr2 cause the reduction of Sox9 expression and result in XY sex reversal [Colvin et al., 2001; Kim et al., 2007; Bagheri-Fam et al., 2008]. In the latter, SOX9 directly binds to the promoter of the Ptgds gene which encodes prostaglandin D synthase that mediates the production of $\mathrm{PGD}_{2}$ [Wilhelm et al., 2007]. Autocrine and/or paracrine $\mathrm{PGD}_{2}$ signaling promotes nuclear translocation of SOX9 and thereby facilitates Sertoli cell differentiation [Malki et al., 2005; Wilhelm et al., 2005]. In XY gonads with a targeted null mutation of Ptgds (Ptgds ${ }^{-/-}$), Sox9 expression is reduced and it appears to take longer for SOX9 to locate to the nucleus; however, there is generally still sufficient SOX9 to allow testis differentiation [Moniot et al., 2009].

Sox 8 and Sox 10 are also up-regulated in the XY gonad, although at lower levels than that of Sox9 [Schepers et al., 2003; Polanco et al., 2010]. The onset of Sox8 expression 
is dependent on the levels of SOX9 since it is reduced in

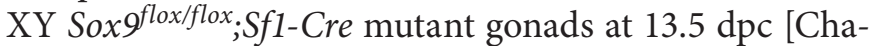
boissier et al., 2004]. On the other hand, Sox 9 expression is intact in the XY Sox $8^{-/-}$null mutant gonad [Sock et al., 2001]. These results suggest that Sox 8 is downstream of Sox9. The function of Sox10 in sex determination is unknown, but several lines of evidence suggest that it may also be involved. For example, human SOX10 maps to $22 \mathrm{q} 13$, where a locus is known to cause $46, \mathrm{XX}$ sex reversal when duplicated [Seeherunvong et al., 2004], and misexpression of a Sox 10 transgene driven by the WT1 promoter causes XX sex reversal in mice [Polanco et al., 2010]. Since both SOX8 and 10 are able to activate expression from TESCO, synergistically with SF1, there might be a feedback loop via TESCO to maintain their expression among SoxE genes.

Other SOX9 direct target genes have been identified. SOX9 is required for the activation of anti-Müllerian hormone gene $(\mathrm{Amh})$, also known as Müllerian inhibitory substance (MIS) which encodes a TGF- $\beta$-like molecule secreted by fetal Sertoli cells. Targeted mutations of the SOX9-binding site in a proximal regulatory region $5^{\prime}$ to Amh in mice gives rise to pseudohermaphroditism with no initiation of Amh transcription [Arango et al., 1999]. This binding site is enriched in SOX9 ChIP assays [Sekido and Lovell-Badge, 2008]. Amh expression is also synergistically activated by SF1 and WT1(-KTS) through their binding sites in the same region [Nachtigal et al., 1998]. In human DSS and Denys-Drash syndrome, this synergism might be disrupted by either overexpression of $D A X 1$ or missense mutations in WT1 which allows SF1 to interact predominantly with $D A X 1$. Cbln 4 is another target gene of SOX9 [Bradford et al., 2009], but again no function of $C b \ln 4$ has been clarified in the testis.

One of the key aspects of Sertoli cells in supporting germ cells is to regulate meiosis. After germ cells colonize the fetal gonad, they are exposed to retinoic acid (RA) whose production is catalyzed by retinaldehyde dehydrogenases (ALDHs, also known as RALDHs). RA can be secreted from the mesonephros in both sexes where Aldh1a2 is highly expressed [Bowles et al., 2006], and from somatic cells in the testis because of the male-specific expression of Aldh1a1 [Bowles et al., 2009]. RA exposure initiates germ cells to enter meiosis. In XY gonads, however, this process is inhibited by the $\mathrm{P} 450$ catabolic enzyme CYP26B1 that mediates the degradation of RA [Bowles et al., 2006]. Although there is a claim that meiosis can occur in a RA-independent manner [Kumar et al., 2011], this work did not prove a total absence of RA in

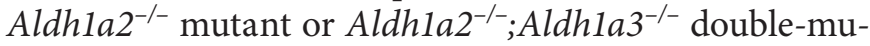

Genetic Control of Testis Development tant testes; moreover it failed to take account of the expression of Aldh1a1 [Griswold et al., 2012]. Cyp26b1 is expressed in Sertoli cells and fetal Leydig cells at $13.5 \mathrm{dpc}$, both of which express Sf1. In Sertoli cells, Cyp26b1 expression is activated synergistically by SOX9 and SF1, whereas it is significantly reduced in the gonads of Sox $9^{\text {flox/flox }}$;Sf1-Cre mice [Kashimada et al., 2011]. Furthermore, FGF9, which is also upregulated in response to SOX9, promotes survival of germ cells after $11.5 \mathrm{dpc}$ and prevents them from entering meiosis at $13.5 \mathrm{dpc}$ [DiNapoli et al., 2006; Bowles et al., 2010].

\section{Somatic Sex-Reprogramming}

Some lower vertebrates, particularly fish, change their sex under certain circumstances even in adulthood, while in mammals the dogma is that sex is irrevocable once determined at the embryonic stage. However, studies in mice with a conditional allele of Foxl $2^{\text {flox/flox }}$ have revealed that ablation of Foxl2 from the adult ovary causes transdifferentiation of granulosa cells to Sertoli cells, using a tamoxifen-inducible Cre integrated in the Rosa26 locus (Rosa26-CreERT2). Data from genetics, ChIP assays, co-transfection, and mutation analysis all suggests that FOXL2 is required to actively repress Sox9 expression in the ovary throughout life. But if FOXL2 function is lost, Sox9 expression is de-repressed in granulosa cells which then transdifferentiate into Sertoli cells. These then organize other aspects of testis differentiation and morphogenesis, including development of seminiferous tubule-like structures, although these are devoid of germ cells and Leydig cells [Uhlenhaut et al., 2009].

The reciprocal transdifferentiation, from Sertoli cells to granulosa cells, has been demonstrated by a conditional loss of Dmrt1 in the adult testis, using Sf1-Cre or DhhCre (see below) [Matson et al., 2011]. In these mutant gonads, granulosa cells expressing FOXL2, CYP19A1/aromatase, and LRH1/NR5A2 appear, and smooth muscle actin (SMA)-positive theca cells are also observed. Germ cells are retained, albeit only a small number, and arrested in meiotic prophase which resembles those in the ovary. Furthermore, ChIP assays in 4 -week-old testes revealed that DMRT1 directly binds to regulatory regions of both testis and ovary-promoting genes, such as Sox8, Sox9, and Ptgdr for the former, and Foxl2, Esr, Wnt4, and Rspol for the latter. The data suggest that DMRT1 functions as an activator for testicular genes and as a repressor for ovarian genes. DMRT1 is a member of the DM domain transcription factor family which was named after 
a homology of the DNA binding domain between Drosophila doublesex (Dsx) and Caenorhabditis elegans mab3. DM domain genes have been found as a sex-determining factor in several organisms. For example, $D s x$ and mab-3 are subjected to a sex-specific alternative splicing and the splicing variants activate the testis or ovary-determining pathway. In the chicken, with homogametic (ZZ) males, DMRT1 maps to the $\mathrm{Z}$ chromosome and a double dose of the gene facilitates testis development [Smith et al., 2009]. The Y-linked DM gene, DMY, acts as the testis-determining gene in some Medaka fish species [Matsuda et al., 2002], whereas the $\mathrm{W}$-linked $D M-W$ promotes ovarian development in Xenopus laevis [Yoshimoto et al., 2008].

DM domain genes may be the ancestral sex-determining factors, and while $S R Y$ has evolved as the switch gene to trigger male development in mammals, DMRT1 has still retained a sex-maintaining activity in mammals. FOXL2 is also evolutionally conserved among animal species in terms of gene structure, expression pattern, and ovary-promoting activity. Postnatal sex-reprogramming in mammals could be achieved by manipulating the evolutionally conserved genes including DMRT1 and FOXL2. Understanding the mechanisms of the sex-reprogramming would shed light on therapies and treatments for human disorders in sexual development.

\section{Leydig Cell Differentiation}

Leydig cells produce androgens, notably testosterone, which masculinize the rest of the body. Fetal Leydig cells appear in the interstitium shortly after testis determination and remain until around birth, when they are replaced by adult Leydig cells [Habert et al., 2001]. However, the origin of Leydig cells has not been fully understood. A prevailing hypothesis is that fetal Leydig cells arise from either the coelomic epithelium covering the early gonad, the mesonephros, or both tissues. In male mice, highly proliferative coelomic epithelial cells migrate into the gonad at $11.0-11.5 \mathrm{dpc}$ and contribute to Sertoli cells and uncharacterized interstitial cells by 12.5 dpc [Karl and Capel, 1998]. The latter population might contain fetal Leydig cell progenitors because migrating coelomic epithelial cells express SF1 [Hatano et al., 1996] which is required for not only Sox 9 up-regulation in Sertoli cells but also activation of genes essential for steroid production, including Cyp11a, P450 side chain cleavage enzyme ( $\mathrm{Scc}$ ), and the steroidogenic acute regulatory protein (StAR) [Morohashi et al., 1992; Sugawara et al., 1996].
Leydig cell-specific ablation of $S f 1$ in mice causes the absence of $S c c$ and $S t A R$ expression as well as delayed formation of testis cord and reduction of cell proliferation. On the other hand, cell migration from the mesonephros begins at $11.5 \mathrm{dpc}$. It was reported that mesonephric cells provide many different cell types such as peritubular myoid cells, interstitial cells, and fetal Leydig cells [Buehr et al., 1993; Martineau et al., 1997; Merchant-Larios and Moreno-Mendoza, 1998; Nishino et al., 2001]. However, recent ex vivo culture assays revealed that no other cell types are derived from the mesonephros than endothelial cells [Cool et al., 2008; Combes et al., 2009]. It was demonstrated that Leydig cells appear in the XY gonad even when dissociated from the mesonephros at $11.5 \mathrm{dpc}$, suggesting that Leydig cell progenitors are already colonized in the gonad through the adrenogonadal primordium before $11.5 \mathrm{dpc}$ [Merchant-Larios et al., 1993]. More recent studies for interstitial development have revealed that there are 2 distinct progenitor populations that are able to contribute to fetal Leydig cells [DeFalco et al., 2011]. The first population originates from the coelomic epithelium as described above. The second population arises from the gonad-mesonephros border region. Both populations express the MAF-B transcription factor. The border cells or perivascular cells are associated with migrating endothelial cells.

Three signaling pathways are involved in the establishment of Leydig cells; desert hedgehog (DHH), platelet-derived growth factor (PDGF), and Notch. In mice, $\mathrm{DHH}$ is produced by Sertoli cells from $11.5 \mathrm{dpc}$ and binds to the Patched1 (PTCH1) receptor that is expressed in interstitial cells [Bitgood et al., 1996; Yao et al., 2002]. Targeted disruption of $D h h\left(D h h^{-/-}\right)$causes reduction of the number of SF1-positive or Scc-positive fetal Leydig cells in the XY gonad, although there appears to be no effect on cell migration from the mesonephros, cell proliferation, or survival [Yao et al., 2002]. This implies that DHH signaling is required to specify fetal Leydig cells. In XY testes carrying a null mutation of PDGF receptor- $\alpha$ $\left(P d g f \mathrm{ra}^{-/}\right), P t c h 1$ expression is dramatically reduced and thereby Scc-positive fetal Leydig cells are also reduced or undetectable. Because mesonephric cell migration and testis cord formation are severely disrupted in the mutant gonad, these defects might secondarily impair Leydig cell differentiation [Brennan et al., 2003]. In the developing gonad, all Notch receptors (i.e. Notch1-4) are expressed in a dynamic fashion. Inhibition of the Notch pathway by targeted loss of the hairy enhancer of split 1 gene $\left(\mathrm{Hes}^{-/-}\right)$, a downstream transcription regulator, leads to a significant increase of the number of fetal Leydig cells [Tang 
et al., 2008]. In contrast, constitutive activation of the pathway within the SF1-positive progenitor population by forced expression of the Notch intracellular domain, which translocates into the nucleus and activates target genes by interacting with HES, inhibits differentiation of the progenitors into fetal Leydig cells.

In the rat, spindle-shape peritubular cells are discovered as adult Leydig stem cells in 7 days post partum testis [Ge et al., 2006]. These cells are negative for $3 \beta$-hydroxysteroid dehydrogenase $(3 \beta-\mathrm{HSD})$ and luteinizing hormone receptor (Lhcgr), but positive for PDGFR- $\alpha$ and are still proliferative in contrast to differentiated adult Leydig cells. They can differentiate into Leydig cells when cultured in a certain condition or transplanted into recipient rat testes. However, it is unknown where the stem cells arise or whether they originate from the same source as fetal Leydig cells do.

\section{Male-Specific Vascularization, Testis Cord Formation, and Cell Proliferation}

Vascular development is a key event during testis formation. In mice, vascular endothelial cells migrate from the mesonephros to the gonad in both sexes, and subsequently the vascularization process becomes sexually dimorphic; the major coelomic vessel and interstitial microvasculature develop in the male gonad, whereas no vessel formation occurs in the coelomic region of the female gonad. This male-specific event is crucial for testis cord formation and cell proliferation, because blocking endothelial cell migration and adhesion by anti-VE-cadherin antibody (VB13) treatments disrupts the cord formation [Combes et al., 2009; Cool et al., 2011]. Four-dimensional time-lapse imaging analyses demonstrated that the XY gonad recruits vasculature by a remodeling mechanism, where endothelial cells composing the mesonephric vessel break down and migrate to the coelomic region through the gonad, whereas the XX gonad recruits it by an angiogenic process [Coveney et al., 2008].

It has been shown that PDGF-B and vascular endothelial growth factor A (VEGF-A) signaling pathways are required for the testis-specific vascular development. Both ligands are predominantly expressed in Sertoli cells and endothelial cells, respectively [Brennan et al., 2003]. PDGF-B expression levels are reduced in VB13-treated XY gonad, while those of PDGF-A are not affected, suggesting that PDGF-B secreted from the endothelial cells induces proliferation of interstitial cells via PDGFR- $\alpha$. Endothelial cell migration, testis cord formation, and cell proliferation are defected in XY $\mathrm{Pdgfra}^{-/}$testes [Brennan et al., 2003]. In addition, genes in the PDGFR pathway are up-regulated in XX $W_{n t 4^{-/-}}$gonads, where ectopic coelomic vasculature develops [Coveney et al., 2007]. VEGF-A is expressed in undifferentiated interstitial mesenchymal cells and its receptors, VEGFR1 (Flt-1), VEGFR2 (Flk-1), and NRP1, are expressed in endothelial cells [Cool et al., 2011]. Administration of a VEGFspecific inhibitor to mouse embryos results in a blockade of vascular endothelial cell migration and impairment of cell proliferation as well as the failure of testis cord formation, although specification of Sertoli cells and Leydig cells is not affected.

\section{Acknowledgements}

The authors are supported by the Medical Research Council in the UK (U117512772). We apologize to those authors whose work was not discussed due to space limitations.

\section{References}

Arango NA, Lovell-Badge R, Behringer RR: Targeted mutagenesis of the endogenous mouse Mis gene promoter: in vivo definition of genetic pathways of vertebrate sexual development. Cell 99:409-419 (1999).

Bagheri-Fam S, Sim H, Bernard P, Jayakody I, Taketo MM, et al: Loss of $F g f r 2$ leads to partial XY sex reversal. Dev Biol 314:71-83 (2008).

Bagheri-Fam S, Sinclair AH, Koopman P, Harley VR: Conserved regulatory modules in the Sox9 testis-specific enhancer predict roles for SOX, TCF/LEF, Forkhead, DMRT, and GATA proteins in vertebrate sex determi- nation. Int J Biochem Cell Biol 42:472-477 (2010).

Bardoni B, Zanaria E, Guioli S, Floridia G, Worley KC, et al: A dosage sensitive locus at chromosome Xp21 Is involved in male to female sex reversal. Nat Genet 7:497-501 (1994).

Barrionuevo F, Bagheri-Fam S, Klattig J, Kist R, Taketo MM, et al: Homozygous inactivation of Sox 9 causes complete XY sex reversal in mice. Biol Reprod 74:195-201 (2006).

Barrionuevo F, Georg I, Scherthan H, Lecureuil C, Guillou F, et al: Testis cord differentiation after the sex determination stage is indepen- dent of Sox9 but fails in the combined absence of Sox9 and Sox8. Dev Biol 327:301-312 (2009).

Bhandari RK, Sadler-Riggleman I, Clement TM, Skinner MK: Basic helix-loop-helix transcription factor TCF21 is a downstream target of the male sex determining gene SRY. PLoS One 6:e19935 (2011).

Biason-Lauber A, Konrad D, Meyer M, DeBeaufort C, Schoenle EJ: Ovaries and female phenotype in a girl with 46,XY karyotype and mutations in the $C B X 2$ gene. Am J Hum Genet 84:658-663 (2009). 
- Birk OS, Casiano DE, Wassif CA, Cogliati T, Zhao LP, et al: The LIM homeobox gene $\operatorname{Lh} x 9$ is essential for mouse gonad formation. Nature 403:909-913 (2000).

- Bishop CE, Whitworth DJ, Qin YJ, Agoulnik AI, Agoulnik IU, et al: A transgenic insertion upstream of Sox9 is associated with dominant XX sex reversal in the mouse. Nat Genet 26:490-494 (2000).

-Bitgood MJ, Shen L, McMahon AP: Sertoli cell signaling by Desert hedgehog regulates the male germline. Curr Biol 6:298-304 (1996).

Bogani D, Siggers P, Brixey R, Warr N, Beddow $S$, et al: Loss of mitogen-activated protein kinase kinase kinase 4 (MAP3K4) reveals a requirement for MAPK signalling in mouse sex determination. PLoS Biol 7:e1000196 (2009).

- Bouma GJ, Albrecht KH, Washburn LL, Recknagel AK, Churchill GA, Eicher EM: Gonadal sex reversal in mutant Dax1 XY mice: a failure to upregulate Sox9 in pre-Sertoli cells. Development 132:3045-3054 (2005).

- Bowles J, Knight D, Smith C, Wilhelm D, Richman J, et al: Retinoid signaling determines germ cell fate in mice. Science 312:596-600 (2006).

Bowles J, Feng CW, Knight D, Smith CA, Roeszler KN, et al: Male-specific expression of Aldh1a1 in mouse and chicken fetal testes: implications for retinoid balance in gonad development. Dev Dyn 238:2073-2080 (2009).

Bowles J, Feng CW, Spiller C, Davidson TL, Jackson A, Koopman P: FGF9 suppresses meiosis and promotes male germ cell fate in mice. Dev Cell 19:440-449 (2010).

- Bradford ST, Hiramatsu R, Maddugoda MP, Bernard P, Chaboissier MC, et al: The cerebellin 4 precursor gene is a direct target of SRY and SOX9 in mice. Biol Reprod 80:1178-1188 (2009).

Brennan J, Tilmann C, Capel B: Pdgfr-alpha mediates testis cord organization and fetal Leydig cell development in the XY gonad. Genes Dev 17:800-810 (2003).

- Buehr M, Gu S, Mclaren A: Mesonephric contribution to testis differentiation in the fetal mouse. Development 117:273-281 (1993).

-Bullejos M, Koopman P: Spatially dynamic expression of Sry in mouse genital ridges. Dev Dyn 221:201-205 (2001).

Bullejos M, Koopman P: Delayed Sry and Sox9 expression in developing mouse gonads underlies B6-Y-DOM sex reversal. Dev Biol 278: 473-481 (2005).

-Canning CA, Lovell-Badge R: Sry and sex determination: how lazy can it be? Trends Genet 18:111-113 (2002).

-Capel B, Swain A, Nicolis S, Hacker A, Walter M, et al: Circular transcripts of the testis-determining gene Sry in adult-mouse testis. Cell 73:1019-1030 (1993).

-Chaboissier MC, Kobayashi A, Vidal VI, Lutzkendorf S, van de Kant HJ, et al: Functional analysis of Sox8 and Sox9 during sex determination in the mouse. Development 131: 1891-1901 (2004).
Clement TM, Bhandari RK, Sadler-Riggleman I, Skinner MK: SRY directly regulates the neurotrophin 3 promoter during male sex determination and testis development in rats. Biol Reprod 85:277-284 (2011).

Colvin JS, Green RP, Schmahl J, Capel B, Ornitz DM: Male-to-female sex reversal in mice lacking fibroblast growth factor 9. Cell 104: 875-889 (2001).

Combes AN, Wilhelm D, Davidson T, Dejana E, Harley V, et al: Endothelial cell migration directs testis cord formation. Dev Biol 326: $112-120$ (2009).

Cool J, Carmona FD, Szucsik JC, Capel B: Peritubular myoid cells are not the migrating population required for testis cord formation in the XY gonad. Sex Dev 2:128-133 (2008).

Cool J, DeFalco TJ, Capel B: Vascular-mesenchymal cross-talk through Vegf and Pdgf drives organ patterning. Proc Natl Acad Sci USA 108:167-172 (2011).

- Coveney D, Ross AJ, Slone JD, Capel B: A microarray analysis of the XX Wnt4 mutant gonad targeted at the identification of genes involved in testis vascular differentiation. Gene Expr Patterns 7:82-92 (2007).

Coveney D, Cool J, Oliver T, Capel B: Four-dimensional analysis of vascularization during primary development of an organ, the gonad. Proc Natl Acad Sci USA 105:7212-7217 (2008).

-Cox JJ, Willatt L, Homfray T, Woods CG: A SOX9 duplication and familial 46, XX developmental testicular disorder. New Engl J Med 364:91-93 (2011).

Cui SY, Ross A, Stallings N, Parker KL, Capel B, Quaggin SE: Disrupted gonadogenesis and male-to-female sex reversal in Pod1 knockout mice. Development 131:4095-4105 (2004).

- Cupp AS, Uzumcu M, Skinner MK: Chemotactic role of neurotropin 3 in the embryonic testis that facilitates male sex determination. Biol Reprod 68:2033-2037 (2003).

DeFalco T, Takahashi S, Capel B: Two distinct origins for Leydig cell progenitors in the fetal testis. Dev Biol 352:14-26 (2011).

Dewing P, Chiang CW, Sinchak K, Sim H, Fernagut $\mathrm{PO}$, et al: Direct regulation of adult brain function by the male-specific factor SRY. Curr Biol 16:415-420 (2006).

DiNapoli L, Batchvarov J, Capel B: FGF9 promotes survival of germ cells in the fetal testis. Development 133:1519-1527 (2006).

Dolci S, Grimaldi P, Geremia R, Pesce M, Rossi $P$ : Identification of a promoter region generating Sry circular transcripts both in germ cells from male adult mice and in male mouse embryonal gonads. Biol Reprod 57: 1128-1135 (1997).

-Eicher EM, Washburn LL, Whitney JB, Morrow KE: Mus poschiavinus $\mathrm{Y}$ chromosome in the C57BL/6J murine genome causes sex reversal. Science 217:535-537 (1982).
Eicher EM, Washburn LL, Schork NJ, Lee BK, Shown EP, et al: Sex-determining genes on mouse autosomes identified by linkage analysis of C57BL/6J-Y-POS sex reversal. Nat Genet 14:206-209 (1996).

- Foster JW, Dominguezsteglich MA, Guioli S, Kwok C, Weller PA, et al: Campomelic dysplasia and autosomal sex reversal caused by mutations in an Sry-related gene. Nature 372: 525-530 (1994).

Ge RS, Dong QA, Sottas CM, Papadopoulos V, Zirkin BR, Hardy MP: In search of rat stem Leydig cells: identification, isolation, and lineage-specific development. Proc Natl Acad Sci USA 103:2719-2724 (2006).

Georg I, Bagheri-Fam S, Knower KC, Wieacker P, Scherer G, Harley VR: Mutations of the SRY-responsive enhancer of SOX9 are uncommon in XY gonadal dysgenesis. Sex Dev 4:321-325 (2010).

Griswold MD, Hogarth CA, Bowles J, Koopman $P$ : Initiating meiosis: the case for retinoic acid. Biol Reprod 86:35 (2012).

Grützner F, Rens W, Tsend-Ayush E, El-Mogharbel N, O'Brien PC, et al: In the platypus a meiotic chain of ten sex chromosomes shares genes with the bird $\mathrm{Z}$ and mammal $\mathrm{X}$ chromosomes. Nature 432:913-917 (2004).

Gubbay J, Collignon J, Koopman P, Capel B, Economou A, et al: A gene mapping to the sex-determining region of the mouse $\mathrm{Y}$ chromosome is a member of a novel family of embryonically expressed genes. Nature 346: 245-250 (1990).

Habert R, Lejeune H, Saez JM: Origin, differentiation and regulation of fetal and adult Leydig cells. Mol Cell Endocrinol 179:47-74 (2001).

Hacker A, Capel B, Goodfellow P, Lovell-Badge R: Expression of Sry, the mouse sex determining gene. Development 121:1603-1614 (1995).

- Hammes A, Guo JK, Lutsch G, Leheste JR, Landrock D, et al: Two splice variants of the Wilms' tumor 1 gene have distinct functions during sex determination and nephron formation. Cell 106:319-329 (2001).

- Hatano O, Takakusu A, Nomura M, Morohashi $\mathrm{K}$ : Identical origin of adrenal cortex and gonad revealed by expression profiles of Ad4BP/SF-1. Genes Cells 1:663-671 (1996).

-Hiramatsu R, Matoba S, Kanai-Azuma M, Tsunekawa N, Katoh-Fukui Y, et al: A critical time window of Sry action in gonadal sex determination in mice. Development 136:129138 (2009).

- Hiramatsu R, Harikae K, Tsunekawa N, Kurohmaru M, Matsuo I, Kanai Y: FGF signaling directs a center-to-pole expansion of tubulogenesis in mouse testis differentiation. Development 137:303-312 (2010).

-Hoyle C, Narvaez V, Alldus G, Lovell-Badge R, Swain A: Daxl expression is dependent on steroidogenic factor 1 in the developing gonad. Mol Endocrinol 16:747-756 (2002). 
-Huang B, Wang SB, Ning Y, Lamb AN, Bartley J: Autosomal XX sex reversal caused by duplication of SOX9. Am J Med Genet 87:349-353 (1999).

- Jeays-Ward K, Hoyle C, Brennan J, Dandonneau M, Alldus G, et al: Endothelial and steroidogenic cell migration are regulated by WNT4 in the developing mammalian gonad. Development 130:3663-3670 (2003).

-Karl J, Capel B: Sertoli cells of the mouse testis originate from the coelomic epithelium. Dev Biol 203:323-333 (1998).

Kashimada K, Svingen T, Feng CW, Pelosi E, Bagheri-Fam $S$, et al: Antagonistic regulation of Cyp26b1 by transcription factors SOX9/SF1 and FOXL2 during gonadal development in mice. FASEB J 25:3561-3569 (2011).

-Katoh-Fukui Y, Tsuchiya R, Shiroishi T, Nakahara $\mathrm{Y}$, Hashimoto N, et al: Male-to-female sex reversal in M33 mutant mice. Nature 393: 688-692 (1998).

-Kim Y, Kobayashi A, Sekido R, DiNapoli L, Brennan J, et al: Fgf9 and Wnt4 act as antagonistic signals to regulate mammalian sex determination. PLoS Biol 4:e187 (2006).

-Kim Y, Bingham N, Sekido R, Parker KL, LovellBadge R, Capel B: Fibroblast growth factor receptor 2 regulates proliferation and Sertoli differentiation during male sex determination. Proc Natl Acad Sci USA 104:1655816563 (2007).

Koopman P, Gubbay J, Vivian N, Goodfellow P, Lovell-Badge R: Male development of chromosomally female mice transgenic for Sry. Nature 351:117-121 (1991).

- Kumar S, Chatzi C, Brade T, Cunningham TJ, Zhao X, Duester G: Sex-specific timing of meiotic initiation is regulated by Cyp26b1 independent of retinoic acid signalling. Nat Commun 2:151 (2011).

Lee CH, Taketo T: Normal onset, but prolonged expression, of Sry gene in the B6.YDOM sexreversed mouse gonad. Dev Biol 165:442452 (1994).

Lin L, Philibert P, Ferraz-de-Souza B, Kelberman D, Homfray T, et al: Heterozygous missense mutations in steroidogenic factor 1 (SF1/Ad4BP, NR5A1) are associated with $46, \mathrm{XY}$ disorders of sex development with normal adrenal function. J Clin Endocr Metab 92:991-999 (2007).

Lovell-Badge R, Canning C, Sekido R: Sex-determining genes in mice: building pathways, in Chadwick D, Goode J (eds): Genetics and Biology of Sex Determination, pp 4-22 (Wiley, London 2002).

Ludbrook LM, Bernard P, Bagheri-Fam S, Ryan J, Sekido R, et al: Excess DAX1 leads to XY ovotesticular disorder of sex development (DSD) in mice by inhibiting steroidogenic factor-1 (SF1) activation of the testis enhancer of SRY-box-9 (Sox9). Endocrinology 153: 1948-1958 (2012).

Luo XR, Ikeda YY, Parker KL: A cell-specific nuclear receptor is essential for adrenal and gonadal development and sexual-differentiation. Cell 77:481-490 (1994).
Malki S, Nef S, Notarnicola C, Thevenet L, Gasca P, et al: Prostaglandin D2 induces nuclear import of the sex-determining factor SOX9 via its CAMP-PKA phosphorylation. EMBO J 24:1798-1809 (2005).

-Mallet D, Bretones P, Michel-Calemard L, Dijoud F, David M, Morel Y: Gonadal dysgenesis without adrenal insufficiency in a 46,XY patient heterozygous for the nonsense C16X mutation: a case of $S F 1$ haploinsufficiency. J Clin Endocr Metab 89:4829-4832 (2004).

-Martineau J, Nordqvist K, Tilmann C, LovellBadge R, Capel B: Male-specific cell migration into the developing gonad. Curr Biol 7: 958-968 (1997).

Matson CK, Murphy MW, Sarver AL, Griswold MD, Bardwell VJ, Zarkower D: DMRT1 prevents female reprogramming in the postnatal mammalian testis. Nature 476:101-104 (2011).

Matsuda M, Nagahama Y, Shinomiya A, Sato T, Matsuda C, et al: DMY is a Y-specific DMdomain gene required for male development in the medaka fish. Nature 417:559-563 (2002).

McCarthy MM, Arnold AP: Reframing sexual differentiation of the brain. Nat Neurosci 14: 677-683 (2011).

-Meeks JJ, Crawford SE, Russell TA, Morohashi K, Weiss J, Jameson JL: Dax1 regulates testis cord organization during gonadal differentiation. Development 130:1029-1036 (2003).

Merchant-Larios H, Moreno-Mendoza N: Mesonephric stromal cells differentiate into Leydig cells in the mouse fetal testis. Exp Cell Res 244:230-238 (1998).

-Merchant-Larios H, Moreno-Mendoza N, Buehr $\mathrm{M}$ : The role of the mesonephros in cell-differentiation and morphogenesis of the mouse fetal testis. Int J Dev Biol 37:407-415 (1993).

Moniot B, Declosmenil F, Barrionuevo F, Scherer G, Aritake K, et al: The PGD2 pathway, independently of FGF9, amplifies SOX9 activity in Sertoli cells during male sexual differentiation. Development 136:1813-1821 (2009).

Montazer-Torbati F, Kocer A, Auguste A, Renault L, Charpigny G, et al: A study of goat SRY protein expression suggests putative new roles for this gene in the developing testis of a species with long-lasting $S R Y$ expression. Dev Dyn 239:3324-3335 (2010).

Morais da Silva S, Hacker A, Harley V, Goodfellow P, Swain A, Lovell-Badge R: Sox 9 expression during gonadal development implies a conserved role for the gene in testis differentiation in mammals and birds. Nat Genet 14: 62-68 (1996).

Morohashi K, Honda S, Inomata Y, Handa H, Omura T: A common trans-acting factor, Ad4-binding protein, to the promoters of steroidogenic P-450s. J Biol Chem 267: 17913-17919 (1992).
Munger SC, Aylor DL, Syed HA, Magwene PM, Threadgill DW, Capel B: Elucidation of the transcription network governing mammalian sex determination by exploiting strainspecific susceptibility to sex reversal. Genes Dev 23:2521-2536 (2009).

- Nachtigal MW, Hirokawa Y, Enyeart-VanHouten DL, Flanagan JN, Hammer GD, Ingraham HA: Wilms' tumor 1 and DAX-1 modulate the orphan nuclear receptor SF-1 in sex-specific gene expression. Cell 93:445454 (1998).

Nagamine CM, Taketo T, Koo GC: Studies on the genetics of tda-1 XY sex reversal in the mouse. Differentiation 33:223-231 (1987).

- Nef S, Verma-Kurvari S, Merenmies J, Vassalli JD, Efstratiadis A, et al: Testis determination requires insulin receptor family function in mice. Nature 426:291-295 (2003).

-Nikolova G, Sinsheimer JS, Eicher EM, Vilain $\mathrm{E}$ : The chromosome 11 region from strain 129 provides protection from sex reversal in XYPOS mice. Genetics 179:419-427 (2008).

-Nishino K, Yamanouchi K, Naito K, Tojo H: Characterization of mesonephric cells that migrate into the XY gonad during testis differentiation. Exp Cell Res 267:225-232 (2001).

Pannetier M, Tilly G, Kocer A, Hudrisier M, Renault $\mathrm{L}$, et al: Goat $S R Y$ induces testis development in XX transgenic mice. FEBS Lett 580:3715-3720 (2006)

- Pearlman A, Loke J, Le Caignec C, White S, Chin $\mathrm{L}$, et al: Mutations in MAP3K1 cause 46,XY disorders of sex development and implicate a common signal transduction pathway in human testis determination. Am J Hum Genet 87:898-904 (2010).

- Polanco JC, Wilhelm D, Davidson TL, Knight D, Koopman P: Sox10 gain-of-function causes $\mathrm{XX}$ sex reversal in mice: implications for human 22q-linked disorders of sex development. Hum Mol Genet 19:506-516 (2010).

-Salas-Cortes L, Jaubert F, Barbaux S, Nessmann C, Bono MR, et al: The human SRY protein is present in fetal and adult Sertoli cells and germ cells. Int J Dev Biol 43:135-140 (1999).

- Schepers G, Wilson M, Wilhelm D, Koopman P. SOX8 is expressed during testis differentiation in mice and synergizes with SF1 to activate the $\mathrm{Amh}$ promoter in vitro. J Biol Chem 278:28101-28108 (2003).

-Schmahl J, Capel B: Cell proliferation is necessary for the determination of male fate in the gonad. Dev Biol 258:264-276 (2003).

- Seeherunvong T, Perera EM, Bao Y, Benke PJ, Benigno A, et al: 46,XX sex reversal with partial duplication of chromosome arm 22q. Am J Med Genet Part A 127A:149-151 (2004).

Sekido R, Lovell-Badge R: Sex determination involves synergistic action of SRY and SF1 on a specific Sox 9 enhancer. Nature 453:930-934 (2008)

-Sekido R, Bar I, Narvaez V, Penny G, LovellBadge R: SOX9 is up-regulated by the transient expression of $S R Y$ specifically in Sertoli cell precursors. Dev Biol 274:271-279 (2004). 
- Sinclair AH, Berta P, Palmer MS, Hawkins JR, Griffiths BL, et al: A gene from the human sex-determining region encodes a protein with homology to a conserved DNA-binding motif. Nature 346:240-244 (1990).

- Smith CA, Roeszler KN, Ohnesorg T, Cummins DM, Farlie PG, et al: The avian Z-linked gene $D M R T 1$ is required for male sex determination in the chicken. Nature 461:267-271 (2009).

- Sock E, Schmidt K, Hermanns-Borgmeyer I, Bosl MR, Wegner M: Idiopathic weight reduction in mice deficient in the high-mobility-group transcription factor Sox8. Mol Cell Biol 21:6951-6959 (2001).

-Sugawara T, Holt JA, Kiriakidou M, Strauss JF: Steroidogenic factor 1-dependent promoter activity of the human steroidogenic acute regulatory protein (StAR) gene. Biochemistry 35:9052-9059 (1996).

-Sutton E, Hughes J, White S, Sekido R, Tan J, et al: Identification of SOX3 as an XX male sex reversal gene in mice and humans. J Clin Invest 121:328-341 (2011).

-Swain A, Narvaez S, Burgoyne P, Camerino G, Lovell-Badge R: Daxl antagonizes Sry action in mammalian sex determination. Nature 391:761-767 (1998).

- Tamura M, Kanno Y, Chuma S, Saito T, Nakatsuji N: Pod-1/Capsulin shows a sex- and stage-dependent expression pattern in the mouse gonad development and represses expression of Ad4BP/SF-1. Mech Dev 102:135144 (2001).

- Tang H, Brennan J, Karl J, Hamada Y, Raetzman L, Capel B: Notch signaling maintains Leydig progenitor cells in the mouse testis. Development 135:3745-3753 (2008).
Tevosian SG, Albrecht KH, Crispino JD, Fujiwara Y, Eicher EM, Orkin SH: Gonadal differentiation, sex determination and normal Sry expression in mice require direct interaction between transcription partners GATA4 and FOG2. Development 129:4627-4634 (2002).

Turner ME, Martin C, Martins AS, Dunmire J, Farkas J, et al: Genomic and expression analysis of multiple Sry loci from a single Rattus norvegicus $\mathrm{Y}$ chromosome. BMC Genet 8:11 (2007).

Uhlenhaut NH, Jakob S, Anlag K, Eisenberger T, Sekido R, et al: Somatic sex reprogramming of adult ovaries to testes by FOXL2 ablation. Cell 139:1130-1142 (2009).

Vainio S, Heikkila M, Kispert A, Chin N, McMahon AP: Female development in mammals is regulated by Wnt- 4 signalling. Nature 397: 405-409 (1999).

- Vetro A, Ciccone R, Giorda R, Patricelli MG, Della Mina E, et al: XX males SRY negative: a confirmed cause of infertility. J Med Genet 48:710-712 (2011).

-Vidal VP, Chaboissier MC, de Rooij DG, Schedl A: Sox9 induces testis development in XX transgenic mice. Nat Genet 28:216-217 (2001).

Wagner T, Wirth J, Meyer J, Zabel B, Held M, et al: Autosomal sex reversal and campomelic dysplasia are caused by mutations in and around the Sry-related gene Sox9. Cell 79: 1111-1120 (1994).

Wallis MC, Waters PD, Graves JA: Sex determination in mammals - before and after the evolution of SRY. Cell Mol Life Sci 65:31823195 (2008).
Washburn LL, Eicher EM: Sex reversal in XY mice caused by dominant mutation on chromosome 17. Nature 303:338-340 (1983).

-White S, Ohnesorg T, Notini A, Roeszler K, Hewitt J, et al: Copy number variation in patients with disorders of sex development due to $46, \mathrm{XY}$ gonadal dysgenesis. PLoS One 6:e17793 (2011).

Wilhelm D, Englert C: The Wilms tumor suppressor WT1 regulates early gonad development by activation of Sf1. Genes Dev 16: 1839-1851 (2002).

Wilhelm D, Martinson F, Bradford S, Wilson MJ, Combes AN, et al: Sertoli cell differentiation is induced both cell-autonomously and through prostaglandin signaling during mammalian sex determination. Dev Biol 287:111-124 (2005).

-Wilhelm D, Hiramatsu R, Mizusaki H, Widjaja $\mathrm{L}$, Combes AN, et al: SOX9 regulates prostaglandin D synthase gene transcription in vivo to ensure testis development. J Biol Chem 282:10553-10560 (2007).

Yao HH, Whoriskey W, Capel B: Desert Hedgehog/Patched 1 signaling specifies fetal Leydig cell fate in testis organogenesis. Genes Dev 16:1433-1440 (2002)

Yoshimoto S, Okada E, Umemoto H, Tamura K, Uno Y, et al: A W-linked DM-domain gene, $D M-W$, participates in primary ovary development in Xenopus laevis. Proc Natl Acad Sci USA 105:2469-2474 (2008).

Yu RN, Ito M, Saunders TL, Camper SA, Jameson JL: Role of Ahch in gonadal development and gametogenesis. Nat Genet 20: 353-357 (1998). 